\title{
Teaching composition with new literacies perspectives: "We'll test it out and then let the kids run with it."
}

\author{
JILL KEDERSHA McCLAY \\ University of Alberta \\ SHELLEY STAGG PETERSON \\ Ontario Institute for Studies in Education
}

\begin{abstract}
We report on two studies of teaching composition in Canadian elementary and middlelevel classrooms, focusing this paper on teachers who work with new literacies perspectives. A study of 21 teachers in all 10 Canadian provinces provided evidence of a broad range of practices in composition instruction, and an ongoing action research study with two groups of teachers allows us to develop richer understandings of the ways in which teachers create curriculum with students to promote engaged and productive multimodal and digital composing practices. Nine themes are discussed within two broad categories: administrative and organizational issues, and teachers' stances and views of selves as learners and collaborators.
\end{abstract}

"I guess for me the choice comes from a place of owning what you want, you know? For me, when I'm taking a course and I am just told what to do, I'm less likely to engage with the material. Whereas, you know, the last project I did for a course I was taking, I did a film. Which is actually sort of what made me do this project with my kids. Because it was the most engaged I've ever felt with course material. And I love school. I love learning. So it just made me think, OK, for my kids who might not feel that way, this might be a good access, an entry point." (Claire, grade 8 teacher in British Columbia)

Like many Canadian literacy teachers, Claire (all teachers' names are pseudonyms) is thoughtfully considering how to teach composition in ways that respect and call upon the literacy world that she and her students meet outside school. She lives with a number of competing tensions - to have students score higher on standardized achievement tests and to offer engaging literacy activities that reflect the real world; to teach an extraordinarily diverse student population and to bring her students' home cultures into her literacy program; to develop strong pedagogical materials for digital learning and to cope with an overburdened school lab; to teach traditional forms of literacy and to help her students participate in the social world of newer forms of composition. Somehow, though, she manages to maintain a balance among these oftencontradictory tensions; moreover, in addition to these and numerous other demands on her energies, she makes time to allow researchers to observe and interview her and her students. She does all this with remarkable good humour and grace. We are indebted to Claire and the many teachers like her who have allowed us into their classrooms as we 
sought to develop an understanding of the current contexts and challenges Canadian teachers face in teaching composition.

In this article, we explore issues and tensions that Canadian teachers negotiate to include new literacies and/or multiliteracies perspectives in their literacy curricula. We report some of the findings from two research studies of the past few years, both of which have focused on how Canadian teachers teach composition to elementary and middlegrades students. The impetus for these two studies grew from our previous national study of the teaching of writing at the middle level, a broad sweep of interviews with 216 teachers in 10 Canadian provinces and two territories (Peterson, McClay \& Main, 2010, 2012). In keeping with literature criticizing teachers in North America and Great Britain for lagging in their integration of digital technologies and Web 2.0 affordances (Alvermann, 2002; Jenkins, Purushotma, Clinton, Weigel, \& Robinson, 2006), the national data from our study suggested that Canadian teachers, though offering strong and conscientious programs based on process approaches to writing, had not generally made a transition to include new literacies perspectives in their composition instruction (Peterson, McClay \& Main, 2012). The discrepancy between the literacy opportunities afforded to young people in schools and those on offer in their out-of-school lives noted by researchers and theorists (Alvermann, 2002; Jenkins et al., 2006) was also found in our national study, as teachers reported using technology in limited ways, and very few discussed exploiting the advantages and opportunities of Web 2.0 affordances. We found that the obstacles they reported included the often-cited ones of limited access to suitable technology; many teachers also explained perspectives that relied on developmental views that indicated their belief that digital composition should follow pencil-and-paper composition, despite a lack of support for such developmental views. (For a more detailed discussion of this finding, see Peterson, McClay \& Main, 2012.)

We noted, however, from our own classroom research (McClay \& Weeks, 2004; McClay, 2006), the national data (Peterson, McClay \& Main, 2010) and our teaching experience with innovative teachers, that there are teachers who do offer students exciting and productive multimodal and digital opportunities for composition. This paper reports on two research projects that followed the original cross-Canada survey. These two studies were designed to develop a more comprehensive understanding of teachers' contexts and challenges for teaching writing. In one study, we recruited a subset of 21 teacher participants from the national study, including teachers in all 10 provinces. Through visits to the teachers' classrooms, we have learned more about their local contexts and everyday practices; moreover, we have seen how, why, and when these 21 teachers integrate technology into their teaching. Although not all teaching of composition involves digital technology, nor should it necessarily, in this article we focus specifically on aspects of new literacies and multimodal teaching that we observed or that teachers discussed with us. We provide examples of their practices and discuss the challenges and issues that they face in teaching composition with digital technology; here, we will not report on broader aspects of their pedagogy or assessment.

The second study is our ongoing action research with teachers to explore potential teaching practices that take up new literacies pedagogical perspectives. This study includes two groups: four teachers in Alberta and two in Ontario. Together, we inquire into ways to balance the teaching of composition with respect to multimodal and new 
literacies with the broader goals of literacy programs and teachers' sensibilities about the needs and interests of their students. The integration of digital technologies and Web 2.0 perspectives is not merely a question of "adding on" but of reconsidering and reconceptualizing many aspects of pedagogy, as we know the barriers-insufficient access, insufficient time, insufficient professional development, tensions with expectations of standardized tests (An \& Reigeluth, 2011; Howley \& Howley, 2008; O'Brien \& Bauer, 2005). In this second study, however, we see teachers who are teaching creatively, engagingly, and very productively with newer technologies and with perspectives that exploit multimodal and Web 2.0 possibilities. Taken together, these two studies provide evidence of teachers who are, in fact, creating dynamic curriculum despite the well-documented obstacles.

We first provide a brief discussion of the theoretical frame of the research; we next explain in more detail the methods of the two studies individually, with a focus on the Canadian contexts in which the research has been conducted; then finally, we turn to presentation of several themes that have arisen from both the completed and the ongoing research, opening with an illustrative snapshot of a teacher followed by discussion of how we have seen this theme evidenced in the two studies.

\section{Theoretical perspective: Evolving, contingent literacies}

In their discussion of new literacies and what rightly constitutes and encompasses a definition of such complex phenomena and practices, Coiro, Knobel, Lankshear, and Leu (2008) argue for research approaches that are broad, rigorous, and inclusive to explore "the wish to understand better how people encode, receive, and negotiate meanings in the current technological conjuncture" (p. 14). They argue for four characteristics to be considered with regard to new literacies:

First, new technologies for information and communication and new visions for their use require us to bring new potentials to literacy tasks that take place within these technologies....

Second, new literacies are central to full civic, economic, and personal participation in a world community. As a result, they become important to study so that we might provide a more appropriate education for all of our students, in all nations....

Third, new literacies are deictic; they rapidly change as defining technologies change.... New technologies for literacy regularly appear, requiring even newer literacies to be able to use them effectively... New technologies invite experimentation to see what they can do....

Finally, new literacies are multiple, multimodal, and multifaceted. Thus, they benefit from analysis that brings multiple points of view to understanding them. (p.14)

As the very meanings of the terms and practices of literacies evolve in contemporary global society, a focus on teachers as individuals and as members of professional communities of practice is particularly important in educational research. Researchers and teachers, working together, can attend with "bifocal vision" (Bateson, 
1994) to the development of pedagogies that have theoretical and pragmatic vigour. Researchers and teachers reflecting together can sometimes foreground the otherwise taken-for-granted aspects of local contexts, and in so doing, make explicit the influence of these contexts. The first study convinced us of the importance of professional learning communities of teachers, and so we shaped the second study to focus on the work of such teachers. In structuring these two studies, we recognize both the individual creativity of the participating teachers and their membership in professional communities at school, district, or provincial level. While our focus is on the individual teachers and their work with students, we also sought to understand how they regarded and participated in their professional contexts.

In this paper, we provide examples of the work teachers do as they integrate digital technologies with their teaching of composition. Such integration is part of their shift in perspectives, and such shifts cannot be accomplished all at once. They require a continual dialogic cycle of teaching and reflecting, as teachers seek to develop a "parallel pedagogy" (Leander, 2009). Some do so very consciously and deliberately, while others do so in a less deliberative manner as they respond to their students' successes and frustrations with each cycle of efforts.

As teachers work in their particular contexts in terms of access, administrative support, and professional development opportunities and requirements, we find it productive and inspiring to reflect with them. In this article, we have not adopted strict definitions or interpretations of what "should" or "should not" be considered to be new literacies work but rather strive to present teachers' practices and reflections as they make transitions to bring digital, multimodal, and Web 2.0 affordances into their teaching, as they experiment with new technologies "to see what they can do," as noted by Coiro, Knobel, Lankshear, \& Leu (2008, p.14). Our research takes up new literacies as new social practices, perspectives, and multimodal conceptions of writing that emerge with new technologies. These ideas include teachers' work toward shared and distributed knowledge, the use of Web 2.0 affordances for curricular work, multimodality in composition, and consideration of the value of local literacies.

\section{Methodology and analysis of two research studies}

\section{Classroom observations and interviews of composition teachers (2008-11)}

Case study methodology (Cresswell, 1998; Patton, 1990) allowed us to develop a broad-based understanding of Canadian contexts and teachers' practices for writing instruction. Data sources included observations in each of 21 participating teacher's classrooms during writing classes from 2008-2011; interviews with the teacher and 4-6 students per class; and relevant documents (e.g., samples of students' written assignments, district or provincial guidelines or curricula, and professional resources). Our data collection focused on how teachers address the needs of culturally, linguistically, and academically diverse student populations in their classroom writing instruction and how they teach a variety of text forms. The interview questions discussed the lessons that we observed, how the writing assignments fit with other writing students had done/would be doing during the year, resources teachers used to teach the lesson, and how teachers felt that the technology/multi-media contributed to students' writing. 
Our data analysis drew upon grounded theory (Punch, 1998); our perspective was shaped through constant-comparison analysis as the study proceeded (Glaser, 1992; Strauss \& Corbin, 1994). Data analysis was ongoing throughout the study and continued after completion of the data collection.

Participating teachers were from all 10 provinces. As Table 1 indicates, these included 12 urban and 9 rural contexts. The table does not do justice to the broad range of Canadian teaching contexts, however. The population range of the rural schools was from approximately 150 to 1000 inhabitants. The range of urban schools was from small cities to Toronto, with approximately 2.5 million inhabitants. In rural and urban schools alike, we saw many multi-grade classrooms with remarkably diverse student populations; teachers frequently explained the diversity of their students in terms of cultural, linguistic, attitudinal, and social aspects.

Table 1

Number of Classrooms Visited in Each Province

\begin{tabular}{llll} 
Province & Urban & Rural & Grades \\
\hline British Columbia & 2 & 0 & 8,8 \\
Alberta & 0 & 2 & $5,4 / 5$ \\
Saskatchewan & 0 & 2 & 4,6 \\
Manitoba & 2 & 1 & $5,7 / 8$ \\
Ontario & 3 & 0 & $4,5,8$ \\
Quebec & 1 & 0 & 4 \\
New Brunswick & 2 & 1 & $6,7,7 / 8$ \\
Nova Scotia & 0 & 1 & 6 \\
Prince Edward & 0 & 1 & 8 \\
Island & & & \\
Newfoundland & 2 & 1 & $5,7,8$ \\
\hline
\end{tabular}

Collaborative action research studies (2010-present)

Our current study is designed as collaborative action research, within two established teacher communities of practice. In such professional communities, teachers and researchers are well positioned to explore and critique pedagogy for new literacies learning. Action research is a productive approach for educators who seek to bridge a gap between theoretical understanding and classroom practices, as it allows teachers and researchers to explore complex issues together in a relationship of "collaborative resonance" (Cochrane-Smith, 1991) in which we together can achieve a broader and deeper perspective than either group could accomplish alone (McClay, 2006).

There is a strong dialectic between practice and theory in the investigation. The collaboration provides opportunities for teacher and university researchers to reflect on practice, coming to a better understanding of ourselves as teachers, and generating principles and generalizations to gain a deeper understanding of practice (Hubbard \& Power, 1999; Rogers, Noblit \& Ferrell, 1990). Data collection includes classroom 
observations, interviews and conversations individually and as teams, student data (student work, conversations with students, and classroom observations), field notes, and reflective journals, as well as interviews with a district technology consultant (Alberta) and administrators (both schools). Data analysis has been collaborative among researchers and teachers at each school. The two groups have met via Skype to discuss their work.

The teachers are located at two public K-6 elementary schools. Jackie Kindergarten), Ellie (grade three), Dorothy (grade five), and Ken (grade six) teach at a rural Alberta school with a predominantly Aboriginal population. Though teaching at different grade levels, the four often speak about their teaching together. Dorothy and Ken have been school representatives to the district technology committee, and through that work, they were aware of and involved in the work of the other teachers. Their school and district have been impressively proactive in seeking opportunities for technology initiatives, and the teachers have been supported in their work. Sara and Kyrie teach at an urban school with a very culturally diverse population. They co-plan and teach their mixed-grade 5/6 classes frequently, in particular when they do special projects involving digital work. They rely on each other for professional support and continuing learning regarding new literacies practices. The two researchers knew five of the six teachers prior to the beginning of this research relationship, and Dorothy joined the Alberta group because she taught at the school and was already heavily involved with school and district initiatives for technology integration.

Under the umbrella categorization of "collaborative action research," researchers and teachers at the two sites shaped the work to suit their particular needs and approaches. Teachers and researchers met regularly at participating schools or online to talk about the Web 2.0 teaching practices. We discussed and reflected on researchers' weekly observations and teachers' daily observations and then planned ways to expand on what was working and modify what was not working well, according to goals set by the teachers.

From many years of conducting classroom-based research, we strongly believe that teachers must be the sole arbiters of their classroom practice, and that they must make all pedagogical decisions. As researchers, we know that we will have much to learn and to observe however the teachers organize their lessons. Much of the composition instruction we observed does not fall into the realm of "new literacies" composition, for example, but we needed to understand how the traditional and the new fit together in the puzzle of contemporary composition. Due to the vagaries of both school and university schedules, our observations were not as regular or frequent as we had hoped, but that is simply the reality of classroom-based research.

\section{Teachers developing new literacies perspectives and practices}

As we consider the work we have been privileged to do with Canadian teachers in their classrooms and analyze data from the two studies, we note a number of recurring themes that play out in various ways. We begin this discussion with administrative and organizational themes: seeking and securing access to appropriate, up-to-date, functioning equipment - a pre-requisite for innovative teaching - and safeguards of privacy and teaching digital citizenship. Though seemingly "superficial," these issues are 
essential aspects of the ability of teachers to work productively with technology. This is especially true when taking up new literacies perspectives that must allow a certain freedom of online accessibility over and above the simple question of "access" to working, up to date equipment. Administrative and organizational issues require teachers to work in collaboration with colleagues in classrooms and administrative positions. We then turn to the heart of the matter-teachers' stances and views of themselves as learners in collaboration both with other teachers and with students.

\section{Administrative and organizational issues}

\section{Teachers seek resources for technology.}

Snapshot: Claire, a grade 8 teacher in an urban district in British Columbia, successfully applied for a corporate grant from a computer company to have the use of a classroom set of laptop computers for a one-month multimedia video project. The complex project was scheduled, and the students completed preliminary work in anticipation of making videos that coincided with the 2010 Olympics in British Columbia. They had a choice of three types of videos to make, and Claire had developed teaching and assessment materials for each choice. On the scheduled day for delivery of the computers, however, neither the computers nor an explanation of their absence arrived. Claire worked on "plan B," as experienced teachers always do. Two weeks later, without any advance notice, the computers were delivered to the school. Claire's class began their projects with great enthusiasm, as we observed on our research visit. After a week, however, Claire was notified by the computer company that she had to return the laptops on the originally scheduled return date. Frustrated, she knew she could not compress a four-week project into two weeks: "It's a little hard to plan, you know? The students are loving this project, but there's no way we can finish it before the computers will be taken away. I'm not sure how we can bring this together in only one more week. The kids are invested in this-they want to finish their movies. I don't know what we'll do."

We have been struck throughout this research by participating teachers' acceptance of the tasks of fundraising and grantsmanship - tasks that are relatively new expectations for teachers but seemingly essential for those teachers who wish to work in innovative ways and new literacies practices. On their own initiative, or with support from district consultants, teachers have been seeking funding and equipment by writing proposals to their schools' parent councils and an impressive range of potential sponsors in corporations, public and private foundations, school districts, or ministries of education.

Claire's experience and that of another teacher, who reported having a corporate donation of a classroom set of laptops arrive with dead batteries on most of the computers, provide cautionary tales about the feasibility of corporate-school partnerships. Other teachers also reported more successful corporate sponsorships.

A few teachers have entered contests to win digital prizes. For example, in Ontario, grade 5/6 teachers Sara and Kyrie began to search for resources to help them integrate more ICT and online tools into their classroom practices. Eight years ago, they won a contest by sending in a website their classes designed; with their $\$ 10,000$ prize, 
they purchased 4 laptops and a scanner, which they still use. More recently, they combined their grade six and grade two classes to script and produced a digital video, winning first prize in another contest - and an LCD projector and Interactive White Board (IWB).

Parent councils are regular fund-raisers for digital equipment for teachers, and a number of teachers spoke appreciatively of parent efforts on their behalf. Teachers in schools with active and generous parent councils sometimes voiced concern about the schools in which parent councils are not able or dedicated to raise funds for computers and other technology that should now be considered basic equipment for education. Moreover, although teachers have a long history of bringing in their own resources for their classes - including books, paper and art materials, and even furniture-- we see that the ante has been raised, as teachers also use their personal laptops for teaching.

We have a number of anecdotal accounts that suggest that funding for technology is available if teachers seek it. Some school districts certainly provide more support than others in this respect, with technology consultants or other administrators whose jobs include such initiatives. On the other hand, some school districts impose technology on teachers (e.g., putting a SmartBoard into each classroom) with reportedly little consultation with them about their perceived needs. Sometimes, this imposition is a result of a corporate tie-in at the district level - an understandable practice if one only considers the cost of technology; then, however, the question becomes one of how teachers' professional development will be encouraged and supported to make pedagogical use of the technology.

Provincial funding, sometimes from special envelopes for technology integration initiatives, can provide a more coherent approach to technology integration. Alberta's Initiative for School Improvement (AISI), for example, has provided a longstanding structure for applications for sustainable initiatives, and the Alberta teachers in both studies have used AISI money for initiatives, such as an iPad project for early learning, to support innovative pedagogy for new literacies learning and teaching. Pierre, teaching grade 4/5 in Alberta, explained the push-pull of provincial funding:

...it is a chicken and egg argument - did we get innovative because AISI funded our projects, or were we innovative and AISI was there as a source? Since... one of the AISI criteria is sustainability after the funding ends, so we saw all AISI monies as seed money. In the realities of education in the $21^{\text {st }}$ century, we have to decide individually and as a school where our line in the sand is regarding corporate sponsorship.

In New Brunswick, Sharon had substantial funding--\$100000-- for a sound studio. She noted that government funding agencies provided a list of criteria that valued innovation; she described the competitive spirit of the proposals: "The government had lots of money... and our superintendent at the time latched onto it, saying, 'That's our money sitting there, we just have to give them a reason to give it to us." In Saskatchewan, Vicky secured an "Access to Learning" award from the Bill and Melinda Gates Foundation; Chris in Newfoundland and Labrador explained a "cultural connections" grant her school secured through the provincial Arts Council and a private 
foundation. Such special initiatives are impressive, and we can easily see that the teachers we have observed who have worked to secure equipment are highly motivated and energized by their ability to accomplish beneficial, engaging learning opportunities for their students. Across the group of teachers in both studies, the question of access to computers has not been determined by whether the school is located in an urban or rural area, as there are examples of teachers and parent councils taking the initiative to equip classrooms in rural and urban schools.

\section{Technology is always an issue, both in terms of hardware and of access.}

Snapshot: Vicky's grade 6 students in rural Saskatchewan are working on drafts of their writing; using their class set of laptops, they do revisions easily, cutting and pasting from one draft to another. Vicky notes, "There are two class sets of laptops and we also have the computer lab, so we have enough for a class of 25 in each place. So 75 kids can be on.... We all have wireless. It's right outside our door. But the problem with that is if I'm using it here and the teacher across the hall is using the other set, and there's a computer class in the lab, half of the computers are down, they can't get access because it's overloaded. So that's a problem, but they're working on it."

Vicky's experience mirrored that of both rural and urban teachers in our studies. Doreen, a grade 4 teacher in Ontario, spoke of limited access for her language arts class - only one 40-minute block per week was allotted for her use of the computer lab, while her access for science and social studies projects was a bit better. Although the school librarian was amenable to having children use the library computers, Doreen expressed the difficulty of this arrangement: "I can't leave the children unsupervised. I can't have 4 kids on the computer upstairs and the other 21 not." In Newfoundland, grade 7 teacher Jonathan noted the pedagogical strain of limited access to the computer lab in his school: "We've got to share it with the rest of the building. We do use it [the computer lab], when there's final drafts of extended projects and such....You've kind of got to book everything in advance, and think way long-term, which we should. If we're planning properly we should consider other people's feelings, schedules and stuff." Laudable as this goal is, it can interfere with a teacher's ability to be flexible to respond to students' needs. Inflexible and limited scheduling can preclude digital work, as some teachers do not feel that in such arrangements they can provide responsible supervision of students.

The frustrations expressed by teachers participating in our two research studies are mirrored in the literature on technology use in schools (An \& Reigeluth, 2011; Ertmer et al., 2012). Our two recent studies indicate that the situation has improved for some Canadian teachers since our 2006-09 national study (Peterson, McClay, \& Main, 2010), when one teacher referred to the only computer in her classroom as the "turtle" because it was so slow. For example, Chris, teaching grade 5 in Newfoundland, noted that her school situation was improving after fund-raising efforts brought in more computers. She had previously expressed frustration with the lack of computers: "It's difficult with writing, unless they're doing it in pairs, when you've only got 8 computers and you've got 30 kids."

As facilities improve, and with professional learning initiatives, teachers and students develop more uses for whatever technology is available. Lara, teaching grade 4 
in Quebec, for example, noted the improvement of her new SmartBoard, as the previous one, a portable, caused her students to trip over the cables. She was aware of other forthcoming improvements in her school:

We're hoping to get more laptops next year because...I guess it was the government had given money to the schools here in Quebec for every classroom to have a Smartboard, and also I think we decided to buy another set of laptops.

We already have, I think, 24 on a cart but, like I said, they don't work that great; the Internet's often down.

Teachers participating in our two research studies explained that the access issue is never-ending - having computers or other technology, and having it all run properly, does not alleviate the continuing pressure for more and better computer and technological facilities.

\section{District policies and individual preferences regarding security and digital citizenship impact teaching.}

Snapshot: Albertan grade 3 teacher Ellie notes that policies are changing regarding posting children's work and images on the Internet. Like many other districts throughout the country, her district had restrictions both on the kinds of identifying information that could be posted about children and about the kinds of information and sources that children would have access to in the school. She notes that, with time, policies are changing regarding posting children's information: "...that was the worry, what kind of information we put out there, but now that it's been around and...people are realizing now, what can be done without there being a danger." Though she acknowledges necessary cautions, she also sees that newer practices, specifically the use of iPads in the classroom, are making policies looser:

I find the iPads make that [loosening security and filters] happen, because you don't login, and so there have been things that teachers can access on the laptops and students can't because we have a looser sort of firewall for staff. But...you just get onto the network and work with the iPads. So now YouTube is open for all students and everything, right? And so, of course, you have to teach some skills, but...it can't be controlled as much.

Security and safety, often defined in vague but all-encompassing ways, are overwhelming concerns for participating teachers. Among the teachers who develop new literacies pedagogy in their classrooms, however, we saw a spirit of thoughtful attention not only to potential dangers in allowing students to join the online world in their schoolwork, but also to the very real benefits of such participation. These teachers spoke carefully about the ways in which they manage student access to information and student posting of personal information. Kyrie and Sara, in grades 5/6 in Ontario, for example, make sure that their wiki and blog sites are not searchable and monitor students' posts on a regular basis. Other participating teachers spoke about working with district tech people to manage blog and wiki sites, as well as school-sponsored student email accounts.

Bringing Web 2.0 into classrooms also raises the issue of digital citizenship in terms of acknowledgement of sources. Teachers who are working extensively with webbased research and writing spoke about teaching their students about plagiarism and 
citation. Claire taught her students to cite their online sources appropriately and to use only image and audio sites that allow free use, with citations. She noted, "Our last lesson was on copyright and citation, which is a big issue. And the students don't really realize that...they can't just take things from the Internet. So that's been really good for them, I think... They've been going only to copyright free sites. They have to take their own pictures, create their own music, which is good." Charlotte, teaching grade 5 in Saskatchewan, echoed this idea, "I was telling them what plagiarizing is, and you cannot plagiarize, because if you do, you're in all kinds of trouble."

Teachers'stances and views of selves as learners and collaborators

Teachers work from social constructivist perspectives in which they are co-learners.

Snapshot: Doug, an Ontario grade 7/8 teacher who described himself as "Mr. Technology" in his school, was pleased to learn from and with his students. He reported on one such occurrence:

This student is really savvy with computers. He said, "Mr. C, all you have to do is use Control $+f$. Open up your find key and you can use the find function on this web page." Why didn't I think of that? So I stopped the class and showed the students how to use this shortcut."

In the spirit of social construction of knowledge, participating teachers, such as Doug, spoke often of co-learning with their students. Garth, a New Brunswick grade 6/7/8 teacher, provided evidence of more spontaneous learning opportunities: "A lot of times we're learning together, and you see this when a student will say, 'You know what else you can do?' and you're [both] learning." Teachers often reported that many of their students are quite knowledgeable about the programs they use in class, and students serve as problem-solvers for groups or the whole class. We note that while excellent teachers have always considered themselves to be learners alongside their students, technology brings this quality to the forefront. Kyrie and Sara deliberately plan for co-learning. They aim to learn something well enough to be able to introduce it to their students, and then they and their students work through it together. As Kyrie explained, "A lot of time we don't want to become experts in it. We'll test it out and then let the kids run with it."

\section{Collaboration is vitally important for professional learning and new literacies teaching.}

Snapshot: Sara and Kyrie regularly spend long hours after school co-planning their co-taught lessons. One evening, Shelley found them working in one of the classrooms at her post-secondary institution. Being graduate students at the time, Sara and Kyrie were used to working at the university. They had been asked by the school janitor to leave the school because he was locking up for the evening. The two teachers decided that the university would provide a good space for them to continue planning, so they set up their materials and worked late into the night at the university. These cotaught lessons, as Shelley observed, were a true back-and-forth between the two teachers. They worked as a team throughout the processes of planning, setting up the wikis and blogs for students, teaching, and assessing/providing feedback to students on their learning. 
New literacies teachers participating in our research show that the shift in thinking and practice needed to develop engaging literacy pedagogy that fosters global participation in literacy environments simply cannot be done alone. Writing grant proposals, problem-solving both on conceptual and technical levels, and the sheer newness of the possibilities that they see in new literacy environments make a collaborative mindset essential for teachers.

In both our research studies new literacies teachers, who are very active in experimenting and reflecting upon new practices, speak with passion about the importance of formal and informal collaboration and professional development in communities of their own choice-sometimes face-to-face and sometimes in online communities. Ellie, in rural Alberta, participates in a vibrant and supportive community in her school but also reads teacher blogs to get ideas and discussion. She notes that she tends to read a blog for a while but then often outgrows it and moves on:

So I no longer really go onto that one anymore, but I have now found a whole bunch of blogs that I really like that I wouldn't have known about otherwise, and they are more specifically relevant to me.

Teachers in our two studies explained that collaborative relationships must be genuine and voluntary, not imposed from above by administrators, as teachers must be able to speak honestly and critically about their efforts. Aware, perhaps, that some teachers might be somewhat jaded about overly rosy success stories, Ellie notes the importance of sharing failed efforts as well as successful ones:

I've learned this, just even communicating at staff meetings or if I'm presenting anything to teachers, I talk about all the things that went wrong, ....Y You get more respect from those teachers, and they need to know sometimes all the failings or the difficulties or the headaches, and then they are more willing to listen to the ideas and listen to the positives.

In addition to the imaginative energy needed to develop new practices, there is also typically a lot of organizational work to setting up opportunities for students to compose in new ways. Sara and Kyrie credited the shared workload of their collaborative work for making it possible to carry out the time-consuming set-up for their wiki and blog projects.

District-level support for collaboration can offer useful assistance without stifling teachers' self-direction for professional learning. For example, in British Columbia, Janette explained that her district supported teacher-led grassroots professional development by providing subsidies to study groups for the purchase of books and snacks.

\section{Teachers spend less time in full-class instruction and more time in workshop and small-group structures.}

Snapshot: We observed Claire's grade 8 students working on their video project. She began the class with a very short introduction to remind students of deadlines and to check that they knew what they should accomplish. For the remainder of the 75-minute Language Arts block, students worked productively in groups while she circulated, asking and answering questions and providing guidance. She explained, "What I found, which I wasn't really expecting, is that my instructional time in this project has been very 
minimal....I have had to do very little instruction.... What I've done in each class is provided a little instruction on one focus." She further noted that the newness of the project helped her to respond to students" needs: "I think next time it will be harder for me to be more hands off, because I'll think I know how everything works, and it will be hard for me to sit back. I think that my instinct will be to instruct more, but I don't know if that will necessarily be beneficial for the kids."

A number of teachers spoke to us about a trend toward less and less full-class teaching as they developed new literacies and other digital projects. As these projects often involve complex multimodal work and require online access, the teachers find that students can easily be working on different aspects of the project during class time, so this helps both with resource allocation and with teaching. "Just in time" teaching works best, with more small-group and individual tutorials. Claire explained that she engages in less class-instruction time:

And...what I found, which I wasn't really expecting, is that my instructional time in this project has been very minimal.... I have had had to do very little instruction. Basically the first class we watched the iMovie tutorials on how to use it, and the kids sort of took notes on what they thought was necessary, and they just went from there.... What I've done in each class is provided a little instruction on one focus.

Jackie noted the satisfaction that comes from attending to individuals and small groups rather than spending much time in full-class teaching. She is better able to pay attention to individuals and to know where they are and what they need at any given moment. In so doing, her students' productivity and feelings of success increase, as they do not get to the point of frustration before receiving guidance.

\section{Students are composing a wide range of multimodal and Web 2.0 texts in their school work.}

Snapshot: Teaching grade 6 in rural Alberta in a school with predominantly Aboriginal students, Ken has developed a project on the Iroquois Confederacy that becomes slightly more complex each year. Working in groups, his students choose an inquiry focus and research that aspect of the Iroquois culture. Students add information to their group wiki as they research, using online and print and visual texts. Several members of the First Nations community who are musicians have recorded music for the students to use in their projects. After amassing sufficient information on their topics, students individually create a digital movie, often taking a personal perspective to create a character and explain an aspect of the culture. Students each write their script and read it as a voiceover, mixing in music with the audio to accompany the text and images. Ken noted both the time commitment required in this project and the pay-off in terms of good results on the provincial achievement exam:

There are some challenges though-the biggest one is that it takes a lot of time, so it's a big commitment. But in talking with a colleague who's done it with me, [we know] you are covering a lot of social studies outcomes and not just the content and the knowledge outcomes on the Iroquois, but a lot of the skill outcomes as well-researching and collaborating and forming and backing up your opinion and things like that; so that's been really good. And also a lot of language 
outcomes as well, so, yes, it does take a lot of time and it's a big commitment, but we've realized this year that we're covering a lot more than we thought we were in terms of outcomes.

Participating teachers found the basic structure of wikis to be very useful for group work. They provide organizational advantages, as students learn with each other, and build on each other's input; they are not dependent on who is absent or present each day; the work is revisable by each member; and the teacher knows who has contributed each part of the research. Moreover, a wiki provides easy organization for students.

Sara and Kyrie, for example, regularly use wikis for their students to work in small groups to gather and organize information in jot notes on social studies and science topics. The two teachers find student-appropriate web sites for the research, provide time for students to read and take notes from the sites that are posted on the wiki, and encourage students to edit and revise each other's notes and to provide accompanying messages in the chat section of the wiki as they negotiate the changes. Students then use the group-compiled notes to create individual book covers, synthesizing the wiki information and incorporating images.

\section{Teachers provide imaginative, integrative contexts to encourage students to compose.}

Snapshot: In Pierre's rural Alberta school, teachers organize school-wide projects; when we observed at the school, the project culminated in a Medieval Days Festival. The Medieval theme had been decided the preceding spring, so teachers had had a lot of planning time to incorporate the topic into additional classroom work if they wished. The Festival was an ingenious blend of old and new practices and technologies, as multi-grade "tribes" of children made shields, helmets, castles, and coats of armour; individually, children wrote about how they "slay the dragons" in their lives. A highlight of the day was an interactive videoconference with "King Alfred," who answered children's questions about life in medieval times. After the video feed had some glitches, "King Alfred" drew a laugh from the children by noting, "We don't have this technology that you use. We occasionally have witches who put spells on things."

In this school-wide project, teachers set an imaginative context for student learning, integrating social studies, language arts, and art in high-tech and low-tech ways. While the video conference [arranged and paid for through www.vccontentproviders.org] and students' subsequent digital stories required digital capabilities, the project also involved considerable multimodal work of a low-tech, messy paint-and-paper variety. The entire project offered a collaborative, integrative dramatic context for student learning (Wagner, 1984).

In another school, Sharon, teaching grade 8 students in New Brunswick, talked about linking project-based learning with "Understanding by Design":

I went to a workshop on problem-based learning...that's probably changed my last three months...because we came up with what I think will be an amazing project for kids - doing a media campaign for service groups. I really want them to focus on the SPCA....For years [in education] it felt like everything was pulling in different directions, ... [but] now I feel we're getting a pretty cohesive idea of what it takes to teach kids well, help them be successful, and it fits. Project-based learning is 
probably and the next, and $21^{\text {st }}$ century learning are the next two big things....That fits well with Understanding by Design, because when you talk about project-based learning, you're talking about knowing....You'd better know what you want kids to know, you'd better design it well, you'd better plan it well....

The authentic contexts that research has shown are important for fostering students' commitment to writing and to improving as writers (Graves, 1994) were a natural part of these multi-media composition projects. The two projects highlighted above provide an interesting contrast in the ways in which teachers can develop imaginative contexts for highly engaged student learning-from the historical Medieval theme, with its fantasy elements, to the contemporary service-learning project the puts students in positions of doing genuine good in their community. In both projects, teachers used online resources to connect their students to the world outside their classrooms, and they did so in ways that exploit the potential of online learning while directly, explicitly fostering student engagement in composition projects.

\section{Teachers foster students' engagement with local and broader contexts.}

Snapshot: With her kindergarten class in rural Alberta, Jackie established relationships with two other kindergarten classes-one in Georgia and one in Wisconsin. The classes developed relationships by posting videos taken on their iPads, as well as sending small packages through the mail to each other. For one of the first exchanges, Jackie asked each of her students what they wanted to tell the children far away. She told about one child, who barely spoke at all in school, participated: "One girl I had...said she wanted to tell the people far away how cold it was outside." Together, they pulled out her outer clothing from her locker, and the child named each item that she wore outdoors. With the other school, the class videoed and discussed plants that grow in their regions, tying in the discussion with foods they eat.

In Jackie's and other schools, we saw teachers eager to make connections between their classes and the wider world. Often, the wider world can be quite close geographically but a distance culturally. Ken set up a literature circles in which his grade 6 students read and responded to a novel with another group of grade 6 students from another part of his school district. Though both classes were within one district, the student population at one school was predominantly Aboriginal, while the population of the other school was predominantly Caucasian. The novel they read focused on questions of racism, and students shared perspectives through their responses to the characters and situations in the novel.

In rural Manitoba, Gwen created a highly imaginative context for her students, drawing upon the local landscape to help them imagine a character and tone for composition. She created a PowerPoint set of slides and text detailing the cabin of an old trapper in the local area. The text described the narrator's thoughts about driving by the house and seeing the smoke coming from the chimney. One day, the smoke was not there anymore, and the narrator noted that someone told her that the old trapper had died. The narrator wondered who the man was, noting that she had never learned his name or anything about him. Gwen used her multimodal text to invite students to imagine the trapper's life and to write about it. In this project, she brought in local knowledge and cultural artifacts to set the imaginative context (Barton, 1998). 
Whether capitalizing on local people and landscapes or looking farther afield, teachers in our studies were keen to engage students beyond the classroom. Some of these efforts involved technology in essential ways-Jackie, for example, knew that her kindergarten class would not have been able to develop relationships through their writing alone-while others used technology to accentuate aspects in particular ways. Ken noted that although both classes of grade 6 students were aware of the other class' predominant backgrounds, the use of technology for their literature circles meant that they discussed racism with perhaps more candor than they might otherwise have done.

\section{Conclusions}

Teachers participating in our two studies have not been sheltered from the many well-documented challenges to taking up a new literacies perspective to teach writing in elementary and middle-grade classrooms (An \& Reigeluth, 2011; Howley \& Howley, 2008; O’Brien \& Bauer, 2005). Yet, many have found ways to bring new literacies and other digital and multimodal perspectives into their teaching of composition in spite of the challenges. They have proceeded from the belief that they can work with colleagues to overcome whatever barriers arise at a given time. They are not prepared to put a hold on new literacies projects as they wait for someone else to solve the problems. These teachers learn as they go, and they expect that students will help them learn. Their energy and commitment to providing engaging and valuable learning opportunities for their students is evident in all aspects of their professional work.

From coast to coast to coast in Canada, there are innovative teachers who create vibrant, engaging curriculum with their students. They cope with whatever technology they have and get on with the job. Teachers consider the potential value to spark their students' interests, never worrying about whether a practice or technology is old or new. Just as Leander (2009) advocated blending traditional and new in "parallel pedagogy," we see teachers for whom the parallels are seamless.

We note a common denominator in these teachers' practices: They work collaboratively and have the potential to influence other teachers' practices because of these collaborations. Raphael (2009) asserts that school reform proceeds not by lone teachers in isolated classrooms but rather on a school-by-school and system basis in teams "with members that cut across traditional work groups." So, too, do we see that teachers must work collaboratively, with support from administrators at the school and district level. In collaborations, they find necessary support to solve problems and to spur further growth. These collaborations create new cultures within schools and districts, and online accessibility enables teachers to seek out like-minded colleagues near and far. They consider their students to be collaborative partners, and, when opportunities arise, they invite research colleagues as well. They expect to keep learning, to stumble occasionally, and to try alternate plans; they are happy to be models to their students of such trial and error learning but also of the extensive planning that contributes to success. Canadian teachers, compared to many of their counterparts in other English-speaking countries, enjoy much freedom to innovate and plan curriculum. Such freedom is essential for teachers to explore new literacies practices and perspectives.

The teachers in our two studies have demonstrated in their classroom practices and informal conversation a tremendous spirit of inquiry and eagerness to try new 
projects, to improve upon previous projects, and to focus intensely on the needs of their students. Both in research and in teaching, they explore, with energy and persistence, "the wish to understand better how people encode, receive, and negotiate meanings in the current technological conjuncture" (Coiro, Knobel, Lankshear, \& Leu, 2008, p. 14). They demonstrate, on a daily basis, amidst the complex demands and responsibilities inherent in teaching literacy in Canadian schools, the four characteristics that Coiro, Knobel, Lankshear, \& Leu (2008) argue as central to new literacies: they bring new potential to the tasks of literacy education; they foster participation in local and global communities; they take up new technologies and experiment with their affordances; and they attend to literacy as "multiple, multimodal, and multifaceted" (p. 14). Perhaps Jonathan, a grade 7 teacher in Newfoundland, sums up the feeling best: "Every year I re-invent myself as a teacher. So next year, I'm going to..."

Acknowledgements: We are tremendously in debt to the remarkable teachers who opened their classroom doors and invited us in. They took time in their busy weeks to talk with us and to allow their students to talk with us. We have learned so much from them. We also acknowledge with gratitude the support of the Social Sciences and Humanities Research Council of Canada and the International Reading Association Elva Knight Grant. We also wish to express our appreciation for graduate student assistance from Christine Portier, Carol Doyle-Jones, Rhonda Nixon, Vera Janjic-Watrich, and Shannon Letendre.

\section{References}

Alvermann, D. E. (Ed.). (2002). Adolescents and literacies in a digital world (Vol. 7). NY, Washington DC, Bern: Peter Lang.

An, Y-J., \& Reigeluth, C. (2011). Creating technology-enhanced, learner-centered classrooms: K-12 teachers' beliefs, perceptions, barriers, and support needs. Journal of Digital Learning in Teacher Education, 28(2), 54-62.

Bateson, M. C. (1994). Peripheral Visions: Learning along the way. New York: HarperCollins Publishers.

Barton, D. (1998). Local literacies: Reading and writing in one community. London: Routledge.

Cochrane-Smith, M. (1991). Reinventing student teaching. Journal of Teacher Education, 42: 2, 104-118.

Coiro, J., Knobel, M., Lankshear, C., \& Leu, D. (2008). Central issues in new literacies and new literacies research. In J. Coiro, M. Knobel, C. Lankshear \& D. Leu (Eds.), Handbook of Research on New Literacies (pp. 1-21). New York \& London: Lawrence Erlbaum Associates.

Cresswell, J. W. (1998). Qualitative inquiry and research design: Choosing among five traditions. Thousand Oaks CA: Sage Publications.

Ertmer, P. A., Ottenbreit-Leftwich, A. T., Sadik, O., Sendurur, E., \& Sendurur, P. (2012). Teacher beliefs and technology integration practices: A critical relationship. Computers \& Education, 59(2), 423-435.

Glaser, B. (1992). Basics of grounded theory analysis. Mill Valley, CA: Sociology Press. Graves, D. (1994). A fresh look at writing. Portsmouth, NH: Heinemann. 
Howley, A., \& Howley, C. (2008). Planning for technology integration: Is the agenda overrated or underappreciated. Educational Planning, 17(1), 1-17.

Hubbard, R. S. \& Power, B. M. (1999) Living the questions: A guide for teacherresearchers. Portland, ME: Stenhouse.

Jenkins, H., Purushotma, R., Clinton, K., Weigel, M., \& Robinson, A. J. (2006). Confronting the Challenges of Participatory Culture: Media Education for the 21st Century. Retrieved http://digitallearning.macfound.org/atf/cf/\%7B7E45C7E0A3E0-4B89-AC9C-E807E1B0AE4E\%7D/JENKINS_WHITE_PAPER.PDF

Leander, K. (2009). Composing with Old and New Media: Toward a Parallel Pedagogy. In V. Carrington \& M. Robinson (Eds.), Digital Literacies: Social Learning and Classroom Practices (pp. 147-163). Los Angeles/London: United Kingdom Literacy Association/SAGE Publications Ltd.

McClay, J. K. (2006). Collaborating with Teachers and Students in Multiliteracies Research: "Se hace camino al andar". Alberta Journal of Educational Research, 52(3), 182-195.

McClay, J.K., \& Weeks, P. (2004). Ensemble Improvisation: Chats, Mystery, and Narrative in a Multiliteracy Classroom. The International Journal of Learning, 10, 1443-1455.

O’Brien, D. G., \& Bauer, E. B. (2005). New literacies and the institution of old learning. Reading Research Quarterly, 40(1), 120-131.

Patton, M.Q. (1990). Qualitative evaluation and research methods (2nd ed.). Newbury Park, CA: Sage.

Peterson, S. S., McClay, J., \& Main, K. (2010). Teaching Writing in Canadian MiddleGrades Classrooms: A National Study. Middle Grades Research Journal, 5(2), 77-90.

Peterson, S. S., McClay, J., \& Main, K. (2012). An Analysis of Large-Scale Writing Assessments in Canada (Grades 5-8). Alberta Journal of Educational Research, 57(4), 424-445.

Punch, K. (1998). Introduction to social research: Quantitative and qualitative approaches. London: Sage.

Raphael, T. (2009) Defying gravity: Whole school literacy reform in urban schools. Literacy Research Association Oscar Causey address. Retrieved from http://www.literacyresearchassociation.org/conference/conf09/videos.html

Rogers, L., Noblit, W., \& Ferrell, P. (1990). Action research as an agent for developing teacher's communicative competence. Theory into Practice, 29(3), 179 -184.

Strauss, A., \& Corbin, J. (1994). Grounded theory methodology: An overview. In N. K. Denzin, \& Y. S. Lincoln (Eds.), Handbook of qualitative research. (pp. 273-285). Thousand Oaks, CA: Sage.

Wagner, D. (1984). Dorothy Heathcote: Drama as a learning medium. London: Hutchinson. 


\section{Author Biographies}

Jill Kedersha McClay is Professor of Elementary Education and Associate Dean, Faculty of Graduate Studies and Research at the University of Alberta. She teaches graduate and undergraduate courses in language and literacy, particular in writing pedagogy.

Shelley Stagg Peterson, a former rural Alberta elementary teacher, conducts research and teaches graduate literacy courses, with a focus on writing and children's literature, in the Department of Curriculum, Teaching and Learning at OISE/ University of Toronto. 